\title{
Perseguindo suas Finalidades
}

É

dá indole do regime democrático a remodelação periódica dos quadros politico-administrativos.

O Departamento Administrativo do Serviço Público não poderia e não deveria, portanto, apesar de seu caráter de órgão essencialmente técnico, fugit à regra. Na ordem natural das coisas e para sua própria sobrevivência, era necessário que seu corpo dirigente passasse por naturais modificações.

A nova direção-geral do D.A.S.P., bem como algumas substituições nos postos de gerência intermediária, deverão propiciar, lògicamente, modificações na politica a ser desenvolvida nas múltiplas tarefas de assessoramento dêste órgão à Presidência da República.

Mesmo sem a recomposição de todos os postos e niveis de gerência, ainda assim se processou - como era de esperar-se - impacto de diferentes personalidades na antiga estrutura e, de novas interações, resultaram renovadas atitudes de revitalização de velhos suportes do Departamento.

O Departamento Administrativo do Serviço Público continua, pois, esforçando-se por cumprir suás finalidades.

Como órgão "staff" da Presidência da República, não poderá deixar o D.A.S.P. de, seguidamente, pesquisar, prever, planejar e organizar nos setores governamentais.

Não se louva o afastamento de uns. Não se conta a chegada de outros. O que se registra, e para o que se chama a atenção, é sim, o fenômeno da dinâmica da direção: a organização formal, estrutural, regimentail ou mesmo regulamentar sofrendo benèficar mente com a transfusão de sangue nôvo, alma nova e idéias novas ou renovadas. Com outra direção qualificada há, sem dúvida, processo fortalecido de dinamização, entusiasmo redobrado e redefinição de objetivos que perseguia. 
Não se despreza o que já se fêz. Mas é da natureza um eterno recomeçar, partindo do estágio anteriormente alcançado. Sem essas funções básicas, o Departamento não assistitá, com eficiência, a chefia maior do Pais em suas atividades fundamentais de dirigit, coordenar e controlar superiormente a Administração Adjetiva dá União.

Centralizando em alto grau atividades que se enquadram nas funções auxiliares de Administração de Pessoal. Administração Orçámentária, Administração Documental, Edifícios Públicos e Relações Públicas, cobre o D.A.S.P. áreas de significação expressiva para os Serviços Públicos Federais.

É evidente que, em cada um dêsses campos, muito já se realizou, mas, sem discussão, bem mais ainda existe por fazer-se. Ë o tropismo para estudos sucessivamente melhores.

Sob o ângulo do assessoramento ao mais alto magistrado da nação, a experiência do D.A.S.P. é cada vez mais respeitável e dêle poderá servir-se, com reais vantagens, o Presidente da República.

No que respeita a Pessoal, bastaria, para se aquilatar da significaação do D.A.S.P. na órbita do Govêrno Federăl, a aplicaçâo da Lei n. 3.780/61, sôbre Classificação de Cargos, com as forçosas e inevitáveis implicações relativas a especificaç̧ões, enquadramento, readaptações, promoções, acessos, quadros especifícos para os Ministérios, e conseqüente centralização maciça dos concursos. Pois dispóe o art. 55, que ao D.A.S.P. caberão os encargos de seleção não só do pessoal para os Ministérios e órgãos subordinados ao Presidente da República, mas, também, das autarquias, entidades paraestatais, Instituto Brasileiro de Geografia e Estatística, Instituto Brasileiro do Caf́e e Serviços Portuários e Maritimos administrados pela União.

Relativamente a Material, são unânimes os entendidos e a experiência vem confirmando que a ação do D.A.S.P., no passádo, foi benéfica à simplificicação, à padronização, à especifíicação, à recuperação, enfim, à racionalização da Administração de Material, maxime ao funcionamento de um sistema disciplinador.

No campo Orçamentário, é ainda o D.A.S.P. peça de valiá comprovada. A história da evoluçấo técnica dos orçamentos públicos no Brasil está indissolùvelmente ligada ao D.A.S.P. como 
órgão fundamental de seu aprimoramento intrinseco e, sobretudo, de seu aperfeiçoamento formal.

A teoria da organização encontra no Departamento o seu maior divulgador - é êle mesmo o melhor exemplo que se poderá dar da teoria dos Departamentos de Administração-Geral enunciada por Willougny.

Não fôsse a iniciativa do D.A.S.P. no campo da estatistica administrativa e o respeitável acervo que acumulou de dados pertinentes á projetos e discussões de leis, bastaria a Biblioteca, do Departamento, especializada em administração, para torná-lo, no âmbito da Documentação, importante instituto para os estudiosos e cultores da Assessoria Administrativa no Serviço Público.

$V \hat{e}$, pois, a Revista do Serviço Pûblico as modificações nos cargos de direção do D.A.S.P. como fato natural, impositivo, provocador de reorientação defensável. Baseada nas diretrizes iniciais norteadoras das atividades do D.A.S.P., uma supervisão vigorosá poderá lograr novos êxitos e aperfeiçoar vantajosamente velhas práticas. 